\title{
TRANSGRESSING BOUNDARIES OF PRIVATE AND PUBLIC: AUTO-ETHNOGRAPHY AND INTERCULTURAL FUNERALS
}

Jenny Ritchie, Sandy Morrison, Timote Vaioleti and Te Whaiwhaia Ritchie

\begin{abstract}
In this chapter the authors take an auto-ethnographic approach to draw from recent experiences of being integrally involved in the death rituals pertaining to a close family member, ranging across three different cultural backgrounds, all located in Aotearoa New Zealand and involving intercultural complexities. All of these funeral proceedings were unusual circumstances, due to the status of the deceased, meaning that in all three instances, the rituals were very public, due to cultural expectations. Through narrative descriptions, this chapter illuminates the ways in which traditional cultural values are played out in contemporary contexts and their importance in providing a framework of support for the bereaved families through the mourning period, albeit in the public gaze. Despite the impacts of colonization, immigration, and globalization, these traditional practices, passed down through generation after generation,
\end{abstract}

40th Anniversary of Studies in Symbolic Interaction Studies in Symbolic Interaction, Volume 40, 95-126 Copyright (C) 2013 by Emerald Group Publishing Limited All rights of reproduction in any form reserved ISSN: 0163-2396/doi:10.1108/S0163-2396(2013)0000040008 
demonstrate their resilience and contemporary application in service of the emotional and spiritual well-being of the respective collectives.

Keywords: Intercultural; auto-ethnography; funerals; Maori; Tonga; spiritual well-being

\section{INTRODUCTION}

Death rituals and grieving although common to humanity are processes that are enacted in different ways across cultural groups and eras in time. This chapter presents auto-ethnographic perspectives of a set of different funeral experiences experienced by the authors, all of which occurred in 2009 in Aotearoa $^{1}$ New Zealand, across three different cultural communities (Māori, Tongan, Pākehā - New Zealanders of European ancestry). All of the deceased were well-known people, recognised as leaders within their own particular communities, and all had received national recognition for their roles and contributions within these various contexts. In this situation, the grieving process of the families is necessarily shared with the wider community, creating an awareness of a tension between the private and public realms for members of the immediate family.

\section{CULTURAL CONTEXT AND EXPRESSION OF EMOTION}

Emotions arise as a human response when we care deeply. It is acknowledged that the "identification (naming) of particular emotions, the matching of emotion to circumstance, and the appropriateness of showing that emotion are all culturally specific" (West-Newman, 2004, p. 34). From a sociocultural perspective, the enactment of a grieving process will be specific to that family, reflecting their particular mixture of cultures and values and the complexities of their personal circumstances, all played out against the backdrop of the wider sociocultural community and historico-political era.

Aotearoa New Zealand, a small island nation in the South East Pacific, has a total population of 4.4 million, of whom $14.6 \%(565,329)$ are the indigenous Māori, and 67.6\% Pākehā. The number of Tongan people living in New Zealand was counted at 50,478 in the last census in 2006, which comprises $19 \%$ of the total of $6.9 \%$ of people from Pacific Island nations, or 
$0.01311 \%$ of the total population (Statistics New Zealand, Tatauranga Aotearoa, 2011). Māori and Tongan peoples share a Polynesian heritage.

\section{AUTO-ETHNOGRAPHY AS RESEARCH METHODOLOGY}

Auto-ethnography has been defined as "an autobiographical genre of writing and research that displays multiple layers of consciousness, connecting the personal to the cultural" which can serve to "illuminate the culture under study" (Ellis \& Bochner, 2000, p. 733, as cited in Humphreys, 2005, pp. 841-842). Auto-ethnography is a story-telling activity (Jones, 2003). Story-telling has a strong tradition in Indigenous cultures (King, 2005), as a form of knowledge transmission across the generations (Jackson, 2007; Rose, 2000), and therefore has come to be recognized as a powerful tool within Indigenous research (Swadener \& Mutua, 2008). Autoethnography has been described as:

\footnotetext{
a form of self-narrative that places the self within a social context. It is both a method and a text ... [and] can be done by either an anthropologist who is doing "home" or "native" ethnography or by a non-anthropologist/ethnographer. It can also be done by an autobiographer who places the story of his or her life within a story of the social context in which it occurs. (Reed-Danahay, 1997, p. 9, as cited in Humphreys, 2005, p. 841)
}

Auto-ethnography allows for personal voice and ownership of one's lived experiences, as interpreted and related by that particular individual. It does involve a sense of personal exposure and vulnerability, although these factors might be somewhat counteracted by the knowledge that in providing such a personal account, one is contributing an authentic challenge to the hegemonic, bland universalizing of knowledge production offered through other research methodologies in which the subject is rendered invisible (Humphreys, 2005).

Auto-ethnography should not be viewed as an "easy" methodological choice for a researcher, as it involves a deep sense of introspection and reflexivity, from which it can be difficult to extricate oneself for the purposes of an academic exercise. Auto-ethnography moves "from the inside of the author to outward expression, while working to take readers inside themselves and ultimately out again" (Jones, 2003, p. 115). There may be powerful emotions involved, yet simultaneously, a sense that we are not alone in these inward, outward journeys (Adams \& Jones, 2008). In conducting 
a project of auto-ethnography, one attempts to extract meaning from experiences, rather than to offer a purely descriptive account of the lived experience. It is "analytically reflexive," creating spaces for dialogue to extend to include informants beyond the self, thus offering insights into theorizing social and cultural realities (Adams \& Jones, 2008, p. 375).

Whilst all qualitative researchers face the "dual crisis of representation and legitimation" (Atkinson, Coffey, Delamont, Lofland, \& Lofland, 2001, p. 3) there is a deep sense of ethical responsibility involved in autoethnography (Richardson, 2008), since storytelling is imbued with ethics (King, 2003), and not only is the researcher identified as the research subject, also identifiable are the researcher's family and community. This provokes a strong sense of accountability to the collective(s) to which one belongs.

\section{TANGIHANGA}

For Māori, the tangihanga is the ritual response to death, a process that enables the wider collective to share and support the pain of the whanau pani, the immediate family of the deceased. "The Maori world acknowledges the emotional pain of death and the need for relief from ordinary activity, presenting tangi as a therapeutic, symbolic and ritualised process for grieving and healing" (McRae, 2010, p. 28). The rituals of tangihanga (funeral ceremonies) are recognized as performing a significant role within Māori society, one that has endured throughout the sustained period of colonisation.

A distinct Māori ritual, the tangi retains much of its traditional form. Of all Māori ceremonials, it has made the fewest concessions to modern pressures. It is a time set apart, an event governed almost exclusively by Māori rules and conventions. Its temporal and spatial boundaries demarcate it clearly from the mundane concerns of Pākeha-dominated social life. (Sinclair, 1990, p. 231)

In our increasingly secular, busy, technologized and globalized world, the adherence to tangihanga remains, despite the obligations for families to leave jobs and other responsibilities for a period of up to a week. This represents a commitment to Māori values such as kotahitanga (the unity of the collective), wairuatanga (spiritual interconnectedness), and whanaungatanga (relationships). Aroha, the reciprocal obligation toward kin, underpins this heartfelt expressiveness (Pere, 1982/1994), and is therefore, "one of the elements to be considered in any study of Māori attitudes to death" 
(Dansey, 1995, p. 110). The upholding of mana (respect, prestige) underpins this process in the respect that is paid to the deceased and his or her contribution to the collective. The rituals of healing that support the grieving process are a shared commitment and process.

The Māori world answers the rupturing of community and disruption to wellness caused by death through the process of tangi. Tangihanga is the traditional Māori process whereby whānau and community come together to grieve the death of a loved one. Tangi has been a persistent institution and one that has undoubtedly contributed to mourning processes in the Pākehā world. (Edge, Nikora, \& Rua, 2011, p. 2)

According to the late Māori author Harry Dansey, the tangihanga serves as a microcosm for the enactment of Māori tradition and values:

The tangihanga is the major Māori ceremonial occasion. Within its orbit is drawn virtually every phase of Māori custom and belief that exists today. Its strength is such that in spite of Pākeha opposition, criticism and derision for more than a century, it has survived and continues, with many adaptations and changes in form, but with the same purpose and spirit as in the past. (Dansey, 1995, p. 110)

Tangihanga provides some contrast to commonly understood Pākehā traditional beliefs and practices around death and mourning. Pākehā funerals are usually a short ceremony (Sinclair, 1990). The deceased person may be held in a funeral parlor until the time of the funeral. Coffins are usually closed. Many choose cremation over burial. However, Māori tangi usually occurs over at least three days, on a marae (village meeting place), with an open casket:

The Māori - and I am sure this still applies to most Māori - want to see their dead, to have them with them until that ultimate committal to the earth. And most still seem to choose burial rather than cremation. The Pākeha attitude seems more based on the belief, usually unstated, that the dead must be hurried away, hidden from sight. (Dansey, 1995, p. 108)

In contrast to the "stiff upper lip" restraint of the Anglo-Saxon tradition, Māori are expressive of emotions, which are seen as the tangible demonstration of connectedness:

No attempt should be made to hide or avoid an emotional display. Tears should be unrestrained and mingle freely with those of the bereaved. All of this is evidence of aroha, of empathy, sympathy, heart, and sadness and is viewed as a major distinguishing feature of Māori. (Sinclair, 1990, p. 229)

The sharing of grief elicited through the expression of karanga (ceremonial calling), karakia (chants and prayers), whaikorero (oratory), waiata (song), and stories enables a collective sanctioning of emotional 
release, facilitative of a therapeutic process of emotional and spiritual healing.

The following three sections provide auto-ethnographic accounts of the funerals experienced by the authors in 2009. First, Sandy Morrison reflects on her experiences of the funerals of both her sister Taini and uncle Sir Howard Morrison. Second, Timote Vaioleti provides a rich description of the funeral of his brother Reverend Sione Latu Vaioleti. Lastly, Te Whaiwhaia Ritchie and Jenny Ritchie provide a narrative reflection on the funeral of James Ritchie.

\section{TWO TANGIHANGA IN THE MORRISON WHĀNAU}

In this section, I (Sandy Morrison) discuss two major tangihanga that occurred in my family in quick succession. In June 2009, my teina (younger sibling), Taini Morrison, passed suddenly and unexpectedly. In September 2009, my Uncle, Sir Howard Morrison passed although not unexpectedly. For the Morrison family, this was an unprecedented loss. Sir Howard had been head of the family for many years and Taini had been a leading kapa haka (Māori expressive cultural arts) exponent having just performed at the national Matatini Festival in February. We, the family, were only just recovering from the passing of my aunty, Adelaide Maxwell, Sir Howard's sister who had also passed unexpectedly in January 2007. While the repercussions for us as the family live on, I adopt an auto-ethnographic approach to narrate my subjective experience and account of these two tangihanga. In the narrative that follows, I highlight key Māori values and discuss them as part of the tangihanga process with reference also to their historical discourses.

\section{Whānau Context}

It is important to locate these tangihanga experiences within a Māori specific positionality of whakapapa, whanaungatanga, and marae (genealogy, family relationships, and the place of identity). Our village of Ohinemutu is home to the people of Ngāti Whakaue ${ }^{2}$ and many families have relied upon the geothermal resources $(n g \bar{a} w h \bar{a})$ for their functionary and daily rituals. Despite its thin crust of land, it has played host to a myriad of visitors over the generations, many of whom have taken away a very special sensory experience through being immersed in the billowing steam arising from 
the many $n g \bar{a} w h \bar{a}$ (hot pools) which bubble incessantly. The marae (village) is known as Te Papaiouru and like many marae, it is the place where ceremonies are conducted and cultural rituals are perpetuated. It is a symbol of identity providing a place for its people to stand tall and is associated with roles and obligations (Mead, 2003). Standing majestically on the marae is Tamatekapua, the chiefly meeting house of Te Arawa and of whom Ngāti Whakaue have been guardians. Tamatekapua looks directly out to St Faiths Anglican Church, whilst St Michaels Catholic Church stands behind Tamatekapua - indicative of the way that Ngāti Whakaue have embraced both religions. Whakatūria, the dining house stands to the east. This is the village of Ohinemutu, our ancestral domain, our home, and from where we draw our sense of belonging.

Mead (2003) describes whakapapa as "a fundamental attribute and gift of birth. A child is born into a kinship system which is already in place and has been for many generations" (p. 42). Ngāti Whakaue stood in force when we as the families returned Taini and Uncle to Tamatekapua, there to lie amid the spirits of ancestors. The sights and noise of hundreds of voices clothed in black, and chanting "Te Arawa e ..." never fails to arouse emotions. There is unquestionable acceptance that this is the rightful place to mourn and to grieve. From a practical view, the space and the facilities allow for hundreds to be received, fed, and accommodated en masse. From a spiritual view, the meeting house is the physical embodiment of ancestors, who can be felt and recalled to assist the deceased on their pathway to another world.

Returning a loved one to the collective, the hapu//iwi (sub-tribe/tribe) and the marae to which they belong is a reminder of the privilege of belonging to a family, a village, and the wider collective of hapu and iwi. The grief is shared, we are all part of this, and we claim the right to express this grief as a collective. Taini and Uncle now belong to the people and there is much work to be done to ensure that rituals are undertaken and completed with the integrity that Ngāti Whakaue tikanga (cultural values and practice) demands. For some of us, our roles demand our presence in the kitchen ensuring that high standards of food, hygiene, and presentation are maintained throughout the entire tangihanga. For others, the role is to greet and engage in the fine art of whaikorero (oratory) supported by a group who will enhance the speechmaking with appropriate waiata (song). For the whannau pani, the immediate bereaved, the role is to grieve and to receive the multitudes who will come to pay their respects. However, there must always be respect and acknowledgment granted to those performing all these roles; from the kitchen, to the paepae (bench where speakers sit during the welcoming ceremony), to the supporters. It is about everyone knowing 
their role and upholding the spirit of whanaungatanga, the bond that enhances and maintains social relationships. Individuals expect to be supported by their relatives near and distant, but the collective group also expects the support and help of its individuals. In tangi situations, we as whānau simply fall into our roles and obligations.

\title{
Rangatiratanga, Mana, and Manaakitanga \\ (Leadership, Integrity, and Hospitality)
}

The respected Te Arawa leader Sir Peter Tapsell describes rangatiratanga as:

\begin{abstract}
The rangatiratanga of the old Māori meant dignity. On the paepae all the men wore a suit and every woman was neatly dressed in black. They had polished shoes. They had mana. Today you find people in gumboots and a bushman's singlet. The old people never did that. We must inculcate into Māoridom that in order to achieve rangatiratanga it involves discipline - a standard of behaviour .... if you go to a marae you should get dressed. There is protocol and custom. It requires a bit of effort. (as cited in Melbourne, 1995, p. 67)
\end{abstract}

A long and close association with tourism has meant that Whakaue have developed a certain refinement in their behavior which has allowed them to successfully negotiate business deals. Whakaue are people of high standards, exemplary presentation, and impeccable manners. It is all part of maintaining our mana (Morrison, 2010). Mana enhances your standing within the community. For the people of Whakaue, there is a shared understanding of the need to uphold some sort of standard. You are the face of Whakaue.

Both Taini's and Uncle's tangihanga were very public events. Since Sir Howard Morrison was an entertainer of great repute, his tangihanga was also broadcast on national television whereas Taini's stayed with extensive local newspaper coverage and Māori television. This brings new pressures. As well as upholding the mana of the family, there is also the mana of the hapu $\bar{u}$ and $i w i$ to consider. Fortunately our history has meant that on the personal level, our paepae (those positioned to greet arriving guests) is always well dressed, both men and women equally, including during a period of mourning. Organizational logistics need also to rise to a higher level to maintain reputation. To provide an example; during Taini's tangi I understand that eight pigs were delivered to assist with food. However, this was the time when swine flu was rife so rather than take any risks, the cooks politely refused the gifts. Better to err on the side of caution than have anyone suffer later. 
During Uncle's tangi, the uncertainty related to the weather led to discussion as to whether or not to erect a grand marquee with costs, while the need to fulfil obligations of manaakitanga (hospitality and generosity) was simultaneously considered. The marquee was duly agreed to as well as the opening up of the church hall, Te Ao Mārama, to ensure that guests waiting to be welcomed on to the marae could enjoy a cup of tea. Traffic logistics needed to be sorted with local authorities for the days of the final funeral burial services for both Taini and Uncle. On the way to the urupa (cemetery), we took Taini past the school at which she had taught, Rotorua Primary. Uncle had a very grand procession through many of the streets of Rotorua and we stopped outside his favorite drinking place, the Citizens Club, so that a glass of chardonnay could go with him. On both occasions, Te Matarae i o Rehu (the Māori cultural performance group) were splendid in their accompaniment adding a dynamic intensity to the protocols as can be seen in the photograph below. For Uncle's funeral, we all decided that our dress was "number ones" and fresh red roses would be worn. Uncle was class and sophistication epitomized and we know that he would have been proud of us all preserving the mana of the family.

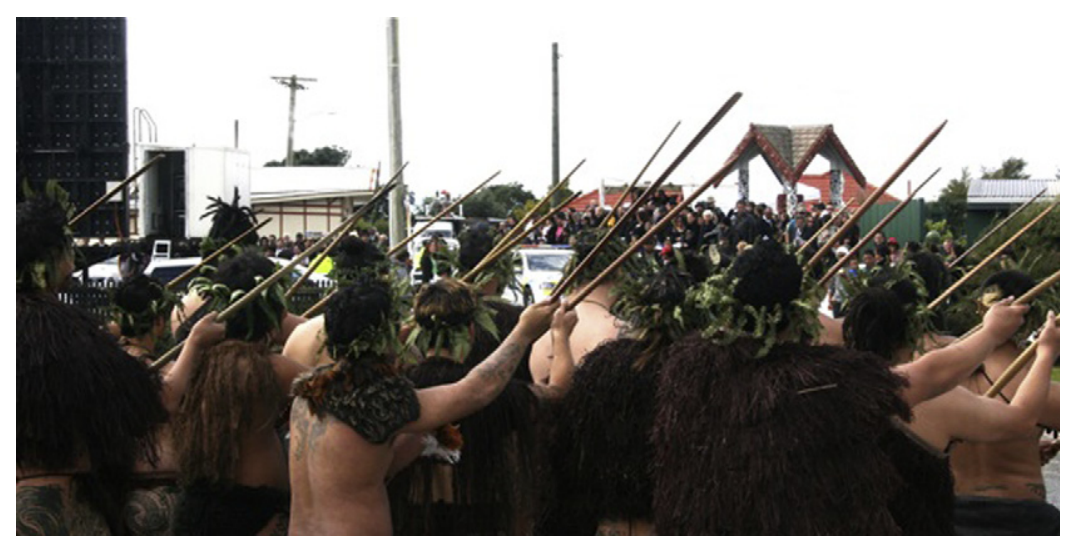

Scene as Sir Howard Leaves Tamatekapua, September 30, 2011. (Photo by Dr. Timote Vaioleti)

Both tangihanga saw grand event arrangement for large numbers, while in contrast, at centre stage was the family, the bereaved. The management of relationships at a traumatic time needed to be constantly negotiated as there is little time to consult, plan, and generally simply share information. 
Tolerance and patience were key words especially as we were conscious of our visibility, being continuously in the gaze of the wider public.

As the flood of manuhiri (visitors, guests) came, we also witnessed manaakitanga in action. Giving and accepting kindness and hospitality bestows mana on both host and guest (Benton, Frame, \& Meredith, 2007). Mead (2003) takes this definition further, stating that "All tikanga (cultural values and practices) are underpinned by the high value placed upon manaakitanga - nurturing relationships, looking after people, and being very careful about how others are treated" (p. 29).

Tikanga and rituals were adjusted to accommodate the unique challenges that the tangi brought. For example, kaumātua (elder) Mitai Rolleston has commented that "we need to show a bit of leniency with our culture. We turn to English to give others the opportunity to speak ... that becomes manaakitanga but we still keep mana" (as cited in Morrison, 2010). Sir Michael Fay spoke at Uncle's tangi in English. He was not the only one to do so and those who were allowed to speak in English spoke with the same intensity of emotion as Māori have in their whaikorero (oratory). Further accommodation was granted on the night before the burial. Usually the poroporoaki (farewell) is a night filled with speechmaking, humour, and song. Taini's last night was very much in accordance with past traditions; however, for Uncle given his "showbiz" nature, the elders agreed to a shortened version of speechmaking to make space for the many entertainers who had arrived to perform for him one last time. A stage was erected complete with all the sound equipment creating a carnival type atmosphere in which all citizens could engage.

\section{Aroha (Unconditional Love)}

Aroha conveys ideas of overwhelming feeling, pity, affectionate passionate yearning, personal warmth toward another, compassion, and empathy, originally especially in the context of strong bonds to people and places (Benton et al., 2007). Mead (2003) reaffirms the interrelatedness of all values saying that aroha is an essential part of manaakitanga and is an expected dimension of whanaungatanga.

As whānau pani (immediate family of the deceased) we sat with heads bowed hearing the calls of welcome, hearing the responses to those calls expressed as karanga (calling by female elders), in haka (ceremonial dance), in pao (song), and in chant. As processions of manuhiri came through the door in their hundreds, the speakers would utter the famous Te Arawa saying "Anō ko te whare whawhao a Te Ao-kapurangi" which translates as: 
"Like the house of previous times, we are overflowing". Significant as the numbers were, for me the importance and meaning was felt in the fact that I was bearing witness to the tangible presence and practice of aroha. I felt it, I saw it, and I read it in the eyes, hearts, and faces of the people. It was transparent and showed open expressions of unconditional love demonstrated time and time again as it flowed from the depth of peoples' souls. "Ko te aroha ano he wai, e pūpū ake ana" (Love is like the wellspring of affection that overflows). My pain was their pain, my tears were their tears. In this space and this time, the depth of human emotion was raw like an open wound and there was no attempt, nor wish, to hide it.

\section{Return to the Whenua (Land)}

The urupa or resting place for Ngāti Whakaue is on the eastern flank of Mt Ngongotahā which overlooks Lake Rotorua. There are many stories of the patupaiarehe or turehu (fairy people) who have occupied the mountain for many generations. Spirited creatures, they are searching for new playmates. Sometimes they signal impending death to a family by visiting and leaving obvious signs of their visit. It is in their care that we entrust our loved ones. There is no easy burial process. After the obligatory last rites and while

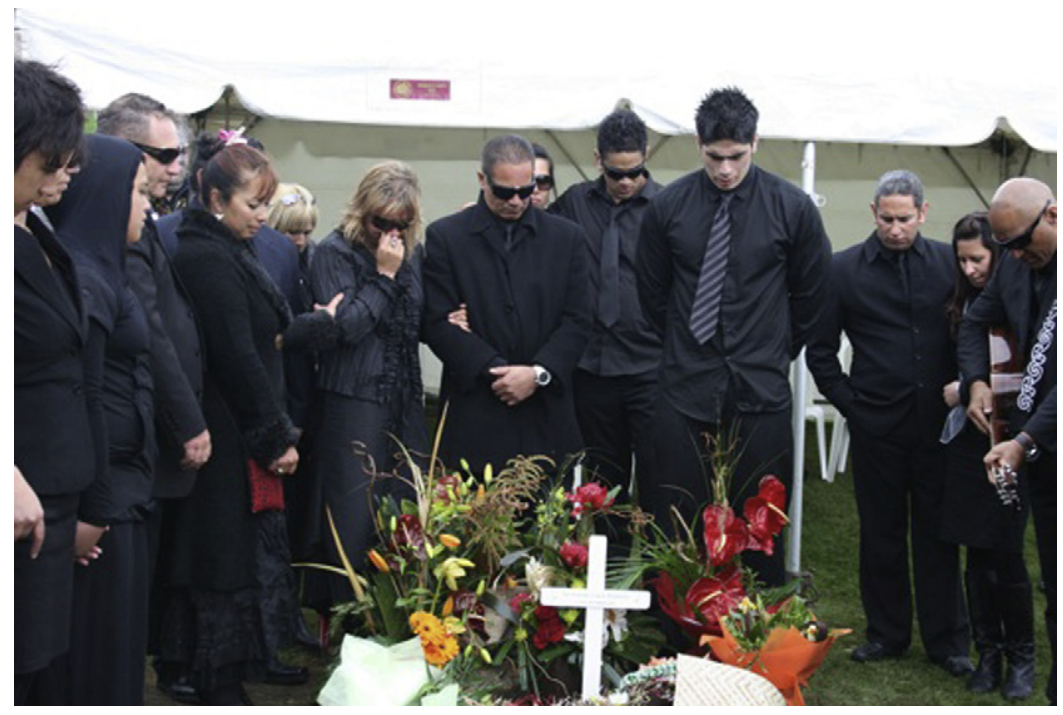

Morrison Whānau, September 30, 2009. (Photo by Sandra L. Morrison) 
people proceed to sprinkle soil or drop a flower, it is usual to sing and haka and generally lighten the load of the bereaved family. After three days of mourning and being caught between Te Ao Wairua (World of the Spirits) and Te Po (darkness) the transition to Te Ao Márama (World of the Physical) is about to begin. Leaving Taini and Uncle there for the first time is heart-wrenching but they lie among their own and the urupa is not a lonely place. The photograph below shows the final karakia being performed by Sir Howard's grand-nephew, Mataia Keepa (fourth from the right). It is frequented often, night and day, and in our absence I believe that the fairies like their own time to play, sing, and dance.

For us, this is a defining moment. The tangihanga process kept us occupied, it brought us stories of Taini and Uncle that we had never heard before; it brought us together as a whānau, hapū, and iwi in which we upheld our mana; we engaged in sharings of unimaginable scale and we were enveloped in the bosom of the collective to be massaged by the demonstration of aroha. Together we began the difficult journey of healing with our people by our side and in the faith and belief that we are not alone. Our grief will continue to be shared as we have laid it before the people who in turn have given us the strength to continue that never-ending journey.

\section{A FUNERAL IN THE TONGAN COMMUNITY IN AOTEAROA}

In a Tongan community, death and the consequent funeral rituals can be the most significant occasion. In such there is a complexity and multiplicity of roles performed for the deceased and relatives which have been long-held traditions. This part of the paper shares some of the unique experiences that defined the funeral of my (Timote Vaioleti's) brother, the Reverend Sione Latu Vaioleti. This funeral process encompassed multiple facets of spiritual expression, including the Christianity that reflected his position as a former regional Head of the Church of Tonga, alongside the old Polynesian spirituality which is contextually performed in Tonga and other parts of the world where Tongan people now live.

\section{Setting the Scene}

It was in the late hours of the 26th of August 2009 that the voice of my sister on the phone informed us that "Kuo hiki a Sione" (literally meaning "Sione 
has moved or shifted") which set in motion the events discussed here. The literal meaning of the above saying points to an understanding from the ancient Tongan religion that death is the beginning of transition from this fonua (land) to Pulotu (the underworld), the fonua of ancestors.

The roles people played at my brother's funeral reflected the contradictions that surround Tongan people in Aotearoa New Zealand, living as we do within the Christian democratic environment and diversified communities of this land. Sione was Western-educated, a public servant who served his Pacific communities and as a result gained the utmost respect of his people. He later became a visionary Head of Church who challenged the establishment to bring its infrastructural and spiritual activities into the 21st century. Yet family and Tongan traditions that connected him to the land and ways of old, some of which I debate in this chapter, belong to the old Tongan spirituality. Sione, like our ancestors, was converted and became the Church's most ardent and rigorous advocate, while still practicing traditions as head of family and ancient ancestral practices.

\section{Methodology}

While drawing upon relevant literature, in writing this material I have relied predominantly on my own knowledge and lived experiences. I have previously explained myself as being locked in a history of encounters (Vaioleti, 2011). This means that I am a product of my own experiences as well as the conscious and unconscious experiences of the people and environment which have shaped me. These cultural eyes continue to give meaning to my world as well as to interpret the worlds of others. I have also used talanoa, ${ }^{3}$ a culturally appropriate research approach for Pacific people, and a development from Pacific Research Methodology (Otsuka, 2005; Vaioleti, 2011; Vaioleti, Morrison, \& Vermeulen, 2002). I suggest that talanoa is the best method to investigate an event that reflects Tongan people, their values, and culture. When my friend Timoti Harris (Talanoa, May 2008), asked "What defines a Tongan?" without hesitation I responded, "It is old religion."

\section{Old Tongan Spirituality and Religions}

The ancient Tonga had many Gods. Some Gods are universal to Polynesia, such as Tangaroa, and are preserved in Tongan as well as other Pacific 
nations' narratives. Some were national, such as Tonga's Hikule'o (literally meaning "guardian of the world end"), the powerful high priestess of the gate to the underworld, Goddess of underworld and fertility. Recognizing such God/s gives us a sense of being part of a bigger system, of identity, as well as their being integral to systems of tapu (spiritual regulatory forces) that provided order to ensure the longevity of relationship and communities. Tapu was applied to relationships between brothers and sisters, male and female relatives, areas and resources dedicated to God/s, or certain people as well as food areas that needed time to recover from harm. God/s were important for spirituality and their presence in social gatherings was important. In the case of funerals, it is a woman that represents Hikule'o.

Acknowledgment of those who are rated highly in a social hierarchy affirms them as well as maintains a sense of order. This acknowledges membership of a bigger system as well as connectedness to others. This act has spiritual qualities. Putting one's self down can make others feel elevated and important members of that group. This is considered humility, on the part of the person who has lowered him/herself, a quality known as anga faka to $\mathrm{ki}$ lalo. ${ }^{4}$ Putting one's self down in the presence of God is like a practical prayer in action. To take that further, humiliating oneself to honor someone who is close to God/s pleases God/s ('Epeli Hau'ofa, Talanoa, May 2004). In the distant past in Tonga, humility was seen as asking favors from the God/s, even by Kings.

Tokiukamea, an English cabin boy rescued and adopted by 'Ulukalala the King of Vavau and Ha'apai, observed how the King's priests hung his dying body over the cooking fire (the lowest form of humiliation) in front of the God/s so that they might cure him (Martin, 1827). Humiliating oneself in ancient times to gain old God/s' favors is still carried out today in Tongan funeral rituals. The origin of these funeral activities seem obscure to most people and are seen as merely cultural, their religious beginnings are not widely known.

\section{Humility, Expression of Grief as Prayer in Action}

For most Tongan people funeral grief is demonstrated by the abandonment of the sense of self, pride, and the usual self-indulgences for a number of days - including care for self, eating, sleeping, and even self-hygiene activities. This observance by the living relatives operates in exchange for favors from Hikule'o to ensure that the journey of their deceased relative 
into her realm is not hindered. In a hierarchical society where rank affords undisturbed and unrivaled privilege to the legitimate owners of those ranks, order and privilege is reaffirmed. Humility is rewarded.

In the past, humility in grief was demonstrated by mourners blackening themselves with dirt and dust, remaining unwashed for days, and depriving themselves of food and rest during the appropriate time of grief. Mourners would wear old ta'ovala (woven mats tied around the waist to mark respect) that were ripped, some of which completely covered the entire body. Nowadays, people wear black clothes as symbolism for the dirt and dust of ancient funeral rituals. During my father's funeral rituals I was to follow these self-sacrifices and rituals, although, since my father was a high-ranking clergyman, the expectation of most Christians was that he had won his place in Heaven already.

For funerals, there is no prescription for the display of grief and expression of emotion (West-Newman, 2004). The funeral for my brother was specific not only to a Tongan family but resides within a sociocultural background that is specific to this particular family. My family's modus operandi is a mixture of old and new religion, old wisdom and modern education, along with the complexities of our personal circumstances as residents of contemporary Aotearoa. The funeral rites were dominated by old religious activities, while simultaneously receiving and caring for all the Church of Tonga branches in Aotearoa, and representatives and other mourners from inside and outside Aotearoa who made presentations during the rituals.

\section{My Brother Sione}

Sione and I were both in Aotearoa toward the end of 1978, when our father passed on. In his funeral service, the President of the Church asked both sides of our family who would be the person to carry hoko. ${ }^{5}$ Sione showed determination and qualities of the cloth so to him fell the legacy to be hoko. A gifted musician, Sione was heavily involved in the music scene, but later took up a position with the New Zealand Police and became one of the first Tongan nation-born Pacific policemen in Aotearoa. While holding a position with the police, he was also one of the first school trustees under the Tomorrow's School system and the founding chair of the South Auckland Pacific Trust, among many other public roles.

As time went on, Sione became more involved in the church youth activities and in a few years he was appointed national Sunday School 
Inspector. Upon his confirmation to the ministry, he enjoyed a meteoric rise to the position of National Secretary of the Church of Tonga (NZ) and was made the Head of the Church of Tonga (NZ) a few years later. Two years later, my mother's brother won the election for the Presidency of the Church, and Sione was made head of the Church of Tonga, USA. In later years, Sione was head of the Church, Southern region (NZ), Vava'u and eventually New Zealand Northern Region (NZ), during which time he passed away.

Sione was a spiritual, loving, and a thinking man but driven and expected similar of people. Whereever he was located, as a church head, he would lead multimillion dollar developments for the benefit of the local people. He advocated for the first Church of Tonga preschool in Aotearoa. He and I designed, fund-raised then led the building of the first Church of Tonga complex in Aotearoa. When Sione passed away in 2009, he was honored by a full traditional and Christian funeral, attended by thousands of ta'ovala gladded mourners. His Christian service shown below was held in the Church, he and I built, Selusalema, the principal Church of the Church of Tonga in Aotearoa.

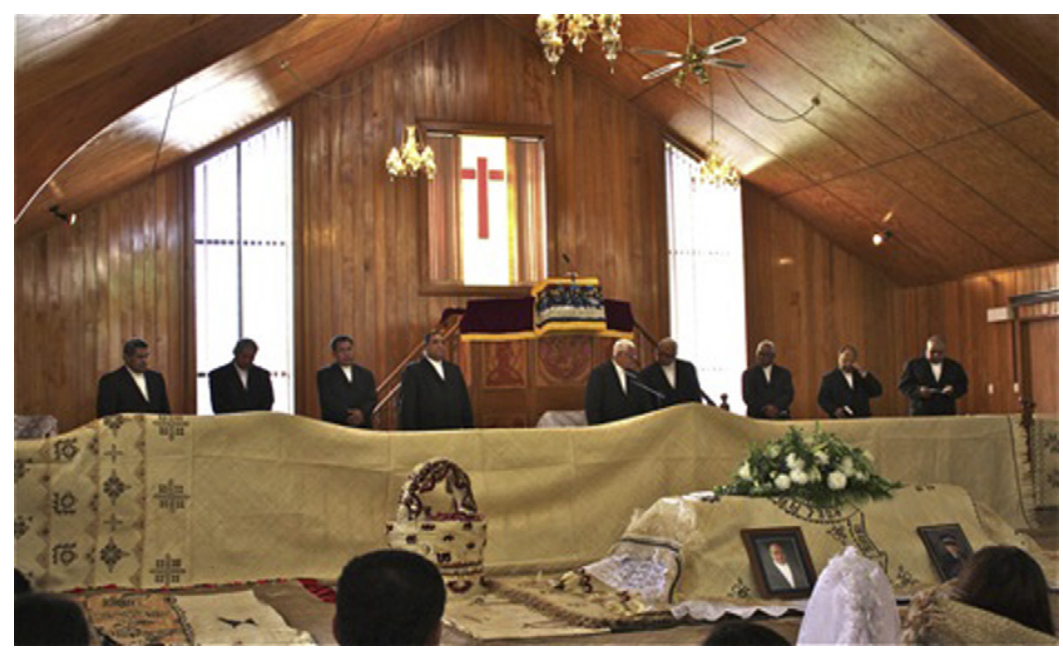

Sione Lying on a Fala Kerekere During his Funeral Service in Selusalema, Mangere, September 1, 2009. (Photo by Cheri Waititi)

Nine ministers conducted Sione's service lead by the former President of the Church. This is a reflection of his rank within the new religion (Christianity) as well as what I see as prayer for his soul too. 


\section{Roles in Funeral Rituals}

Funerals for most Tongan people follow a highly ritualized grieving process. Family members are notified and expected to attend the putu (funeral rites). Tiatia (1998) has suggested that all Tongan, Samoan, and Niuean societies are built on the assumption that everyone knows and performs his/her role well. This is evident in a Tongan funeral.

According to tradition, the paternal side of a family leads the proceedings and provides the food. Sione was the eldest in the paternal side of the family and I was next. My older sister, who is our family's highest ranking person, was also involved in consultations regarding proceedings and logistics. The maternal side prepares the food and gifts for the fahu (highest ranked female elder in an extended family) and fellow mourners. The men of the maternal family dig the grave too. Sione was not moved nor his death announced until arrangements under my guidance had been undertaken. Only then did my younger sister and I travel to inform my father's younger brother (whom we refer to as "father") before we called in to inform the Head of the Church (NZ) before dawn. Interestingly, when we arrived at his residence, he was reading, saying that he had been woken by a single deep cracking of thunder before midnight and had since then been reading and reflecting, as he had felt that "Kuo hiki a Sione."

\section{The Fahu in the Tongan Putu}

Fahu is central to understanding the complexities of relationships and activities that occur in Tongan funeral rituals. The fahu is the highest authority in charge of the funeral ceremony. In my talanoa with 'Epeli Hau'ofa (May 2004), he shared that the respect and even gifts Tongan people bestowed upon certain groups were demonstrated in ancient times in order to please the old Gods. These certain people were considered representatives or closer to the God/s so when things were done to please them, it was believed that the God/s were pleased as well. People regarded as close to the God/s include the Kings or Queens - their children - who are direct descendants of Tangaroa. Their relatives are relatives of Tangaroa too. Others include women who are closer to Hikule'o ('Epeli Hau'ofa, Talanoa, May 2004). When a spirit is in the process of hiki to Pulotu, the domain of Hikule'o, she comes into prominence. The meihikitanga (paternal aunty and often the matriarch) is the likely fahu in a putu.

These days, the fahu is often controversial as she is elevated to almost mythical status. She is addressed in the chiefly dialect, gifted generously with 
koloa (treasures such as ngatu (tapa), fine mats, and other gifts) by relatives of the deceased. This gifting and mystical elevation continues well after the burial. Younger Tongans educated in the equality and secularism of enlightenment discourses may have difficulty comprehending this display of pandering. The fahu is normally seen sitting on rich and finely decorated mats around the head area of the deceased. The deceased on the other hand lies on plain fala kelekele (plain, coarse, undecorated brown earth mats) to continue the sense of humility in the presence of the old God/s Hikule'o.

\section{Rituals After the Burial}

After the Christian service and burial, the continuance of old religion offerings takes another turn. The deceased is now physically in the fonua (tomb, grave), the underworld and in the realm of Hikule'o. The fahu continues to preside over offerings including metaphoric sacrificial acts. In ancient times sacrifices can include cutting off body parts such as fingers in seeking favors from Hikule'a to ensure a safe journey for the loved one now in her realm.

In Aotearoa in the 21st century, however, less dramatic actions are still carried out, involving less invasive sacrifices. In the picture below, my daughter Lora Marie Muna is seen offering the fahu her hair as part of funeral tradition and grief process.

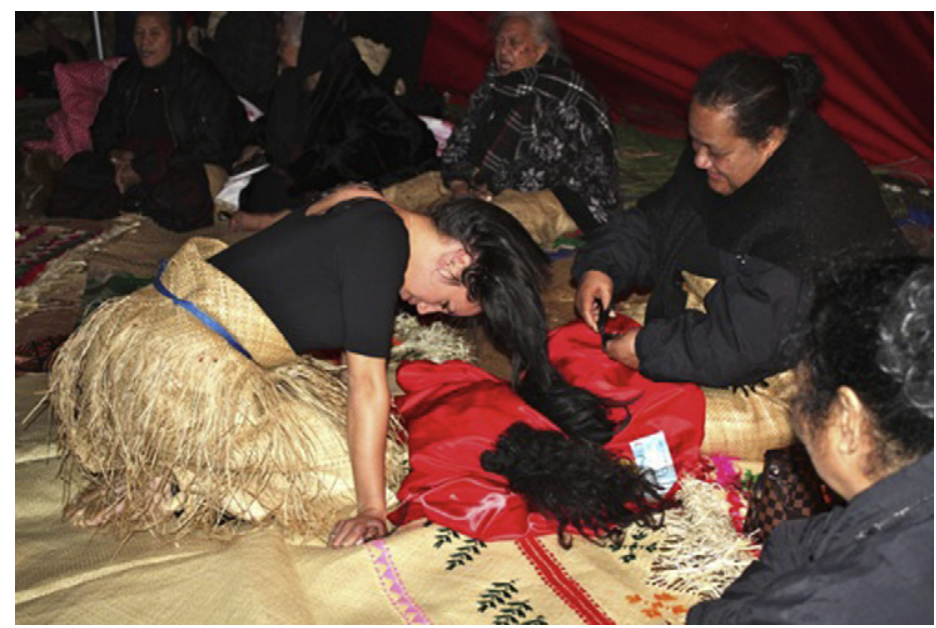

Lora M. Muna Vaioleti Hair Sacrifice, Mangere, September 4, 2009. (Photo by Cheri Waititi) 
It is the position of this chapter that this is part of the ancient showing of grief and humility as a modern day "prayer in action" to the Goddess of Pulotu (underworld) to care for her father" ${ }^{6}$ in his journey. Other relatives, including Sione's own sons and daughters, stayed true to hundreds of years of tradition by having their hair cut as well.

The role of the fahu continues for several days to months. One of the final roles of the fahu is to remove the tapu by sprinkling around a liquid called loloku after the determined one, three, ten days or even months depending on the social rank of the deceased. This marks the end of the funeral rituals, and is followed by a significant gifting by the family to the fahu and others who have prayed and worked to ensure the journey of their loved one to his or her destination is successful. All this work and expenses are cultural expressions of grief and love for a family member kuo hiki.

\section{Reflections}

This section of the chapter, "A Funeral in the Tongan Community in Aotearoa", has illustrated the complex realities faced by Tongan people who attempt to weave together traditions that have served their ancestors of centuries with the beliefs that were introduced by Christianity and western education. In the case of Sione, who was a community person, educated in Tonga, England, and Aotearoa and also a high ranking member of clergy (Head of Church), it is clear that his old Tongan spirituality remained integral to most of the processes, rituals, and grief expressed in his funeral.

Sione's putu rituals were a weaving, a specific mixture, of old and new religions, modern education, and the complexities of our personal circumstances in multiethnic 21st century Aotearoa. It is my wish that our service, our prayer in both action and words, through the gifting and elevation of the fahu for Hikule'o, has successfully ensured the Rev. Sione Latu Vaioleti safe hiki to the next two worlds, Pulotu and Heaven.

\section{THE TANGI OF EMERITUS PROFESSOR JAMES RITCHIE}

Kāpā he tangi huene e kore e mutu, tênā ko tā te tangata ka mutu.

It is not as if it were the unending sound of the sea, that of a person must sometime cease. - Mead \& Grove, 2003, p. 177 
In this section of the paper, Jenny Ritchie draws upon the work of her son, Te Whaiwhaia Ritchie, who undertook an auto-ethnographic narrative study $^{7}$ of the tangi of his grandfather, James Ritchie (T. W. Ritchie, 2010). Interestingly, Te Whaiwhaia's great-grandparents were Ernest and Pearl Beaglehole, ethnographers who as part of their work had studied Māori funeral practices in the 1940s. They had observed that:

\begin{abstract}
All societies in all parts of the world have developed a series of patterns of behaviour and feeling which help the members of the group to come to terms with or adjust to the facts of death. [We] might say that the death of a member of the group ... represents a crisis situation. The job of the cultural patterns is to give the members of the society a method of handling the breakdown so that cultural integration is preserved and those immediately affected by the death are given some technique for coping with the anxieties and sorrows that death occasions. The importance of the study of such death customs lies in the fact that through them we are generally able to perceive the values that the society holds as significant for the living and the dead. $(1945$, p. 91$)$
\end{abstract}

Te Whaiwhaia's grandfather (and Jenny's father), Emeritus Professor James Ritchie (1929-2009) had studied anthropology under Professor Ernest Beaglehole at the Victoria University of Wellington, in the 1950s. James was a Pākehā, born in Wellington of working-class Australian immigrants, who had a long career in academia which began as a teacher in Māori schools in the late 1940s and early 1950s. In his field of cultural psychology, James became a founding professor at the University of Waikato, the instigator of the Centre for Māori Studies at that University, and an advisor to the Tainui tribal leadership, working closely alongside both Sir Robert Mahuta and Dame Te Arikinui Te Atairangikaahu, the late Māori Queen.

\title{
Methodology
}

The phases of this project included a literature review followed by an autoethnographic narrative enquiry. Te Whaiwhaia produced his own written narrative of his feelings and experiences during the days following the death of his grandfather. He then shared this narrative with adult members of his family who had expressed willingness to participate in his project, providing a series of guiding questions with which to frame our responses, which invited us to consider:

- What these events meant to me?

- What stood out?

- What made sense and what did not?

- What I understood and didn't understand

- What aspects of the tangihanga made it feel like a Māori occasion or a Pākehā one? 


\section{Excerpt from Te Whaiwhaia's Narrative}

After our arrival at the hospital room, where my grandfather had recently passed away, it was Tainui kaumātua (elder) Tom Moana who opened the proceedings by beginning a succession of karakia (chants). He spoke in Māori and then finished by reciting the "Pai Marire" chant. Pai Marire is a religious belief system that was adapted by Te Ua Haumene from Christianity in the 19th century and later adopted by King Tâwhiao, thus it is a religion that is very much a part of the Kiingitanga movement, and, therefore, a part of my grandfather. Pai Marire is one chant that my grandfather would always enjoy taking part in, although he was never a religious person.

The next event that took place at the hospital was the arrival of some members of the "Kahui Ariki", which is the aristocracy, or royal family, of the Kiingitanga movement. A party of kaumātua and kuia (female elders) came in and joined the whanau in the already crowded hospital room. They recited further karakia and whaikorero. They brought leaves with them which were laid over my grandfather. This was the "tono", or request that Grandad be brought to their marae at Türangawaewae in Ngāruawahia. My Grandmother Jane agreed. It was during this time that we were alerted to the fact that Sir Howard Morrison had also passed away on the same morning. Once the funeral directors had taken my grandfather to the funeral parlour, Tom Moana cleared the hospital room of the tapu that remained by chanting karakia and sprinkling water around the room. We then went to the funeral parlour to continue with the organisation of the days to come.

We were greeted and supported at the funeral director's premises by close friends and whānau. There was a lot of discussion and decisions were made on matters such as the timing and arrangements for the tangi. My mother and Aunt Helen then dressed my grandfather in some of his favourite clothes which we had brought with us from home. Jane had particularly wanted him to be wearing his manaia (stylised sea-horse carved figure) necklace and his Order of New Zealand Merit medallion. Linda Waimarie Nikora and Ngahuia Te Awekotuku, both former doctoral students of my grandfather, arrived to join us at the funeral parlour, bringing with them a korowai (woven cloak) with which to drape the coffin, and they instructed us in the appropriate tikanga for this.

We arrived back home in the evening to a welcoming party who called us into our house. Paddy Kaa who is a local kaumātua, greeted us with a whaikorero that was replied to by Tom Roa. The two Tainui kaumātua, Tom Moana and Tom Roa, stayed to settle us in, and conducted a final karakia for the evening, promising to return early the next morning to open our day with more karakia. It was with great sensitivity and understanding that when it came to karakia, Tom Roa stepped back and allowed for Tom Moana to conduct Pai Marire instead of a more orthodox Christian prayer. That evening 
the family shared personal stories while my Grandad lay peacefully, the beautiful korowai draping the lower half of his open coffin, his favourite view at his back and his loyal companion Bobby lay at his feet. This would be the last night he would spend in his home.

The next morning, after a seven am Pai Marire karakia session, we set off for Türangawaewae, but first we would stop to pay our respects at the local Raglan marae called Poihakena. We arrived at Türangawaewae Marae around three pm where a large party of people, all dressed in black, was gathering outside the gate. Some faces I recognised, many I did not, some faces acknowledged me, many did not. I was then asked to join my brothers and cousins as a pall-bearer. When signalled, we slowly marched up to the marquee

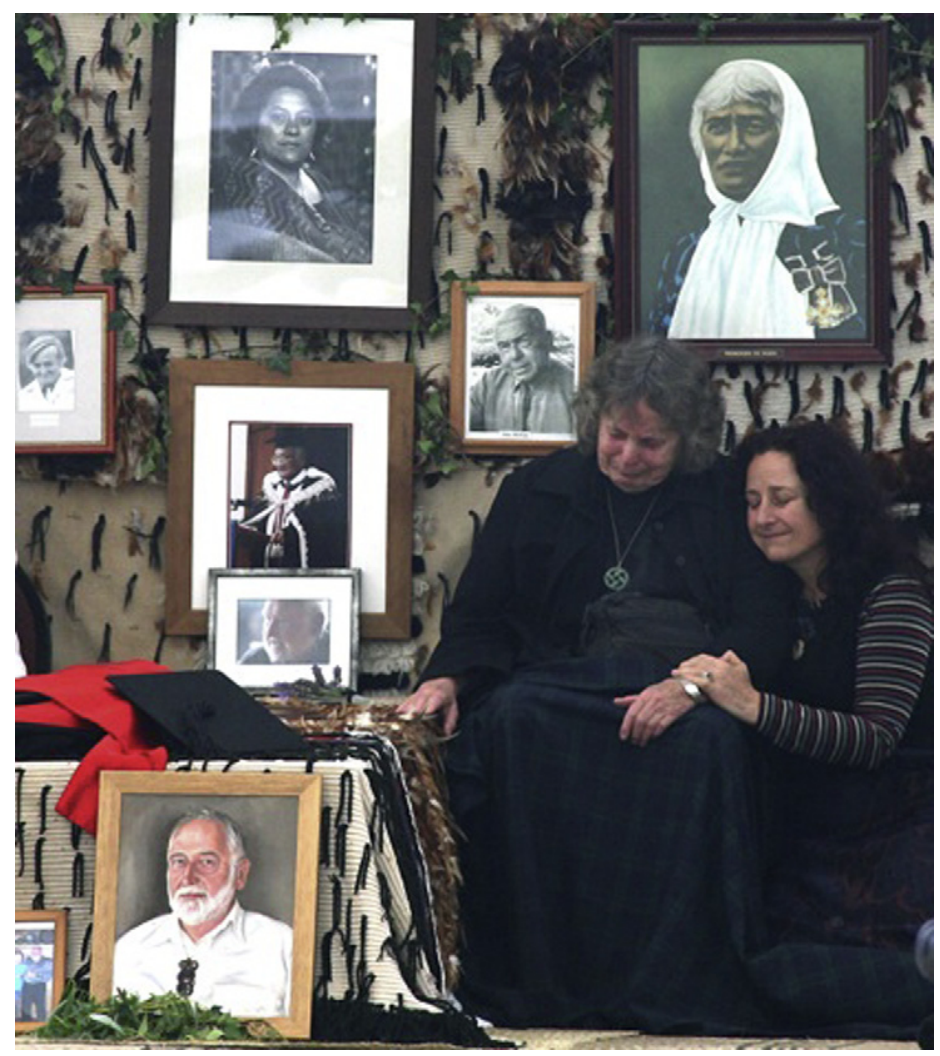

Jane Ritchie and Jenny Ritchie at Tangi of James Ritchie.

(Photo courtesy of the Waikato Times) 
that had been especially set up for this occasion. The kuia (female elder) from the marae began her karanga (welcoming call) and a kuia from the visiting party responded as we slowly made our way to the shelter and laid the tūpāpaku (deceased) down. As we took our places alongside Grandad, we noticed that the screen behind the place where Grandad was to lie had been carefully prepared to display photos of (esteemed Tainui ancestors) Te Atairangikaahu, King Koroki, Sir Robert Māhuta, Te Puea, and so on. My grandmother Jane was provided with a chair as she is unable to sit on the floor, and this was positioned next to my Grandad. The marquee was positioned to the left-hand side of the marae facing directly towards Mahinarangi (the ancestral meeting house), on the opposite side of the courtyard. The doors of Mahinarangi were open. ${ }^{8}$

The whaikorero (welcoming speeches) began once everyone was welcomed and settled into seats, with the male speakers sitting in the front row. In most powhiri (greeting ceremony) situations it is the Māori language alone that is heard from the beginning to the end, but on this occasion it was decided by the elders that following the whaikorero by the kaumatua, there would be an opportunity for speeches to be conducted in te reo Pākeha (English language) as well. This message was conveyed by Tom Roa to those present. This allowed for some incredible oratorical performances, as colleagues shared stories of the memories they had of Grandad. Te Kahautu Maxwell delivered a whaikorero with a rich and colourful list of the achievements that linked Grandad with Tainui and with the Kiingitanga movement. For me, this was one of the more meaningful and well-presented speeches of the tangi. One of Grandad's Pākehā nephews was last to speak, and gave a touching description of the man he called his favourite uncle.

Shortly after this initial powhiri, we were alerted to the fact that another ope (entourage) was approaching. This turned out to be the Māori King, Kiingi Tuheitia, and his party. They were ushered on to the marae without delay and whaikorero began once more. This was not the first time I had been in the presence of the King; there had been past occasions when I was with my Grandad having been his driver to Kiingitanga celebrations over the past few years.

He Whakaaro - Reflections on the Narrative and Responses

As Te Whaiwhaia analyzed the material he had accrued, including his own written narrative, he was particularly interested in noticing comparisons and contrasts between "ngā āhuatanga Māori me ngā āhuatanga Pākehā” (Māori 
and Pākehā ways of being, knowing and doing), since his Pākehā grandfather had been accorded the honor of a tangihanga ceremony on the national marae of Tūrangawaewae in the heart of the rohe (area) of the Tainui tribe which heads the national Māori Kiingitanga movement. Te Whaiwhaia reflected that:

The most immediate thought that comes to mind was that it was overwhelmingly a Māori occasion. This comes as no surprise, for anyone who knew my grandfather would agree that he was a man who truly became bicultural (c.f., J. E. Ritchie, 1992). His thoughts could, and would flow from the Pākeha academic world, where things tended to be categorized and typologically explained, to the Māori world, where things were not so black and white, where ideas were bounded by harsh colonial realities, but secured in webs of tradition, language, and spirituality. He understood and had a profound respect for the Māori world, and he worked hard throughout his whole professional career to make things better for the Māori people.

Although the tangi was indeed a Mäori tangihanga, there is something to be said about the unique way that it became a bicultural tangi. It was not planned to happen that way, but as things progressed, there were intermarriages between what was traditionally Māori, and what was "retro-fitted" to allow for James to be given a more fitting and appropriate send off. The example that jumps from my memory was when Tom Roa asked the kaumätua from Türangawaewae if speeches could be given in Te Reo Pākehā (the Māori language) as well. This was agreed, and thus the academic community with whom James had worked so hard, paid tribute to a colleague, a mentor, a teacher and a dear friend.

For me the tangi meant doing the right thing. It meant a proper recognition of my grandfather's life and the hard work he had done. It meant that the rest of the whanau could move on. It meant that my grandfather was now gone, he was no longer to suffer in the confines of his physical body. This also meant it was time for me to move slowly through the process of mourning, a process that I revisit every day that I write this essay.

\section{Whānau Reflections}

The written responses to Te Whaiwhaia's narrative came from individuals (family members) with varying degrees of cross-cultural understanding. These narratives ranged in length, yet all conveyed a great depth of meaning and emotional insight. Te Whaiwhaia noted that:

There was a common understanding that this occasion was an "honouring" of James' life "in the most significant way possible." This was emphasized by 
the acknowledgement of "how he had touched so many people." The whanau noted "The gentle, sensitive, calm and constant guidance and support" (Mum - Jenny) "by the kaumātua and kuia and Tainui friends of dad at every stage in the process" (Aunty). This guidance was invaluable, since for many of the wider whānau, this was their first experience of a tangi. Even for those closest to Grandad, despite his lifelong involvement in Te Ao Māori, we had never been in the position of having to organise a tangi.

There was agreement that the tangi felt like a "Māori occasion and specifically a Tainui occasion," "9lthough, there was also great appreciation of the allowances for tikanga and kawa to be transgressed to allow, for example, for speeches to be given in te reo Päkehā. Not only were the speeches conducted in both te reo Māori and English, but there was almost a contrast in styles across the whaikorero and speeches, where the Māori whaikorero tended to speak directly to Grandad, acknowledging his work for Tainui and Māoridom as a whole, whereas Pākehā people tended to talk about Grandad, and about how they met Grandad. There was a shared acknowledgement, as well as a sense of surprise at all the hard work, the tautoko/support and the aroha from the many friends and whanau and ringawera (workers) throughout every stage in the process. My uncle, for whom this was his first ever tangi, spoke of how he "was astonished about all the work and effort and feelings by all of those who were involved" (Uncle).

On reflection it was perhaps a strange coincidence that another rangatira (leader) in the Māori world, Sir Howard Morrison, had died on the same day as my Grandad. His tangi coinciding over the same weekend, meant that whilst many people moved in hordes between the two marae, some people didn't manage to attend both tangi. I subsequently met a school-friend of mine, who is a greatnephew of Sir Howard, and we were able to pay each other respects, apologizing for the fact that neither of us had attended the tangi of the other's koro.

Ka mate tino tangata, tēnā e rewa mai.

When an important person dies, people move in hordes.

- Mead \& Grove, 2003, p. 170

\section{REFLECTIONS}

The literature is sparse with regard to research or theorizing pertaining to intercultural funerals. "The interaction between death, grief and culture is an area that has begun to draw attention, yet there appears to be little research which specifically focuses on the diversity of cross-cultural grief expressions" (Edge et al., 2011, p. 2). It has been further suggested that 
a consideration of the "experiences of whannau/family that are configured by both Māori and Pākehā identities, and their engagement with tangi/funerals may increase our understandings around the ways in which such families respond to bereavement and grief and move forward in their lives" (Edge et al., 2011, p. 3).

Sharing their grief with the wider public, including many "strangers" was probably an unanticipated aspect for most of the Ritchie whanau. For many Pākehā, coping with a bereavement is something best done in a private, sequestered manner. This reflects both the individualistic nature of Western societies, and the historical medicalized sequestering of death that resulted from "sickness discourse" during times of pandemic illness, as well as "death-denying" discourses (McRae, 2010).

The scenario of the expectation to participate in an unfamiliar forum of grieving process can potentially be a source of extra stress at a time of bereavement:

Theoretically, whānau/family of dual cultural origin may enjoy the resources of two cultural communities which afford choices of rituals from two cultural worlds. However, the potential for conflict, tension and misunderstanding cannot be ignored. These families may be required to negotiate two sets of cultural values, beliefs and expressions within their bereavement. (Edge et al., 2011, p. 3)

Significantly, our whannau were closely supported through the entire process by Tainui elders as well as Māori colleagues (and former students) of James. The gentle, respectful scaffolding by these people was undoubtedly the bridging process which transcended the potential cultural divide, thus enabling members of the family to feel included in what was for many an unusual experience. However, all were aware of the great respect being accorded to James throughout the proceedings at Türangawaewae. In this instance, through the manaakitanga of the Tainui people at Tūrangawaewae, this public marae setting, and the kawa of tangihanga, offered a forum for access to new ways of being, and in particular, for expressing emotions for Pākehā members of our family who may previously have had limited access to a lived experience of Māori values and culture.

The discussion pertaining to the tangihanga of James Ritchie as related above by his grandson Te Whaiwhaia illuminates a number of considerations. While there has been some critique of discourses pertaining to "biculturalism" over the years (see, e.g., Bell, 2006; Sharp, 1995; Simon, 1989; G. H. Smith, 1992; D. Sullivan, 2007; K. Sullivan, 1993; Tahi, 1995; Vasil, 1988; Walker, 1987c), the reality for many people in Aotearoa is one of shared ancestry. Yet subtle and not-so-subtle attitudes of racist white 
superiority are still present in the background of our everyday interactions as citizens of this country (Bell, 1996, 2006; J. Ritchie, 2005; Spoonley, 1990; Wetherell \& Potter, 1992). Having access to authentic engagement in Māori rituals such as tangihanga have the potential to widen the experience of Pākehā to be more respectful of Māori cultural practices which may, through their inclusivity, collectivity, and spirituality, serve to offer healing pathways at times of crisis and death for both Māori and Pākehā.

\section{HE WHAKAARO WHAKAMUTUNGA - CONCLUDING THOUGHTS}

Auto-ethnography, as demonstrated in the three accounts provided in this chapter, can serve as a methodology which is enabling of the transcending of boundaries of private and public. In assuming the role of "autoethnographers" we veered away from our usual researcher personas, taking a step beyond being an "insider" researcher (L. T. Smith, 1999) to being at the heart of the research focus. This positioning provides an intimate, embodied, emotionally resonant view of close personal, cultural, and spiritual processes, multilayered as sifted through the shared family narratives.

For all three of the families described in this chapter, the frameworks of strong cultural values modeled through the leadership of elders provided the scaffolding for the rituals that enabled expression of grief. These values have endured despite the potential forces of dislocation caused by histories of colonization and immigration. The resilience of these values points to their enduring value as a source of spiritual and emotional well-being.

\section{GLOSSARY}

Tongan terms are italicized, Māori terms are not italicized

anga faka to ki lalo - a disposition toward putting oneself below others aroha - the reciprocal obligation toward kin fahu - highest ranked female elder in an extended family fala kelekele - plain, coarse, undecorated brown earth mats fonu - land which includes life forces and all that are within it, placenta fonua - tomb, grave haka - ceremonial dance hap $\bar{u}$ - sub-tribe 
hiki - transition

Hikule'o - Goddess of underworld and fertility

hoko - the person who must continue a family tradition

iwi - tribe

karakia - chants and prayers

karanga - ceremonial calling

kaumātua - elder

kawa - cultural protocols

Kiingitanga - pan-tribal movement, headed by the Tainui tribe, initiated in the 1860 s as a response to colonization

koloa - treasures

korowai - woven cloak

kotahitanga - the unity of the collective

kuia - female elders

mana - respect, prestige

manaakitanga - hospitality and generosity

manaia - stylized sea-horse carved figure

manuhiri - visitors, guests

marae - village meeting place, the place of identity

meihikitanga - paternal aunty and often the matriarch

ngatu - tapa cloth

ngāwhā - geothermal activity such as hot-springs

ope - entourage

paepae - bench where speakers sit during the welcoming ceremony

Pākehā - New Zealander(s) of European ancestry

pao - song

pōwhiri - ritual of encounter, welcome ceremony

Pulotu - underworld, the fonua of ancestors

putu - funeral rites

rangatira - chief, leader

reo - language

ringawera - marae workers such as cooks and dishwashers

rohe - area

ta'ovala - woven mats tied around the waist to mark respect

Tangaroa - God of the Sea

Tangaroa - Sky God

tangi, tangihanga - funeral ritual

tapu/tapu - spiritual regulatory forces

te reo - the language

teina - younger sibling 


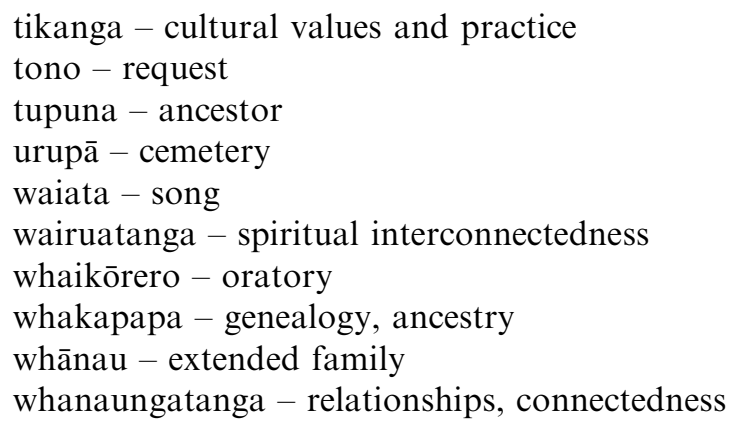

\section{NOTES}

1. Aotearoa is a Māori name for New Zealand. Māori and Tongan terms are explained on first usage, with a glossary provided at the end of this chapter also.

2. Ngāti Whakaue are a sub-tribe of Te Arawa, a large central North Island tribe.

3. Talanoa is a Polynesian term referring to a process of discussion.

4. A disposition toward putting oneself below others.

5. The one that must continue a family tradition.

6. In Tongan culture and ways, because Sione is my brother, he is my children's father as well, not uncle.

7. This project was conducted as a directed study toward a graduate diploma in psychology, under the supervision of Dr. Linda Waimarie Nikora, Associate Professor in Kaupapa Maori Psychology and Director of the Maori and Psychology Research Unit (MPRU). It was commissioned as a contribution to the Tangihanga Research Programme - Aitua, funded by Nga Pae o te Maramatanga Māori Centre of Research Excellence. Te Whaiwhaia and Jenny also acknowledge the following people: Ngā kaumatua me ngā kuia, Tom Moana, me ngā ringa wera nō Turangawaewae; Prof. Ngahuia Te Awekotuku, Asst. Prof. Linda Waimarie Nikora, Mohi Rua, Tom Roa, rātau ko Ngahuia Dixon mai Te Whare Wānanga o Waikato; Hera White; Aunty Nuki; Shane Soloman, Te Mauri Tau; Paddy Kā; me te whānau whānui.

8. Mahinarangi was a great tupuna (ancestress) of the late Tainui Princess Te Puea. Te Puea was instrumental in the building of the famous meetinghouse at Turangawaewae Pā (village) in 1929, which she named after her tupuna. During the tangi we were informed that for the doors of Mahinarangi to be opened for a tangihanga is considered a great honor.

9. The sense of the tangi being a "Tainui occasion" was strongly reflected in the location, Türangawaewae Marae, the marae that is used by Tainui for significant ceremonial events, the whānau pani and guests being hosted by Tainui kaumātua and kuia, and in the kawa (protocols) such as having pōwhiri, karanga, whaikōrero, and the manaakitanga of the Tainui ringawera (marae workers). Different tribes have different variations of these ceremonial traditions. 


\section{REFERENCES}

Adams, T. E., \& Jones, S. H. (2008). Autoethnography is queer. In N. K. Denzin, Y. S. Lincoln \& L. T. Smith (Eds.), Handbook of critical and Indigenous methodologies (pp. 373-390). Los Angeles, CA: Sage.

Atkinson, P., Coffey, A., Delamont, S., Lofland, J., \& Lofland, L. (2001). Editorial introduction. In P. Atkinson, A. Coffey, S. Delamont, J. Lofland \& L. Lofland (Eds.), Handbook of ethnography (pp. 1-7). London: Sage.

Bell, A. (1996). 'We're Just New Zealanders'. Pakeha Identity Politics. In P. Spoonley, C. Mcpherson \& D. Pearson (Eds.), Nga Patai. Racism and ethnic relations in Aotearoa/ New Zealand (pp. 145-158). Palmerston North: Dunmore Press.

Bell, A. (2006). Bifurcation or entanglement? Settler identity and biculturalism in Aotearoa New Zealand. Continuum: Journal of Media \& Culture Studies, 20(2), 253-268.

Benton, R., Frame, A., \& Meredith, P. (Eds.). (2007). Te mātāpunenga: A compendium of references to the concepts and institutions of Māori customary law. Hamilton: Te Mātāhauariki Research Institute at the University of Waikato.

Dansey, H. (1995). A view of death. In M. King (Ed.), Te Ao hurihuri: Aspects of Māoritanga (pp. 105-116). Auckland: Reed.

Edge, K., Nikora, L. W., \& Rua, M. (2011). Different coloured tears: Dual cultural identity and tangihanga. MAI Review, 1. Retrieved from http://review.mai.ac.nz/index.php/MR/ issue/view/23.

Ellis, C. S., \& Bochner, A. (2000). Autoethnography, personal narrative, reflexivity: Researcher as subject. In N. K. Denzin \& Y. S. Lincoln (Eds.), The handbook of qualitative research (pp. 733-768). Thousand Oaks, CA: Sage.

Humphreys, M. (2005). Getting personal: Reflexivity and authoethnographic vignettes. Qualitative Inquiry, 11(6), 840-860.

Jackson, M. (2007). Globalisation and the colonising state of mind. In M. Bargh (Ed.), Resistance: an indigenous response to neoliberalism (pp. 167-182). Wellington: Huia.

Jones, S. H. (2003). The way we were, are and might be: Torch singing as autoethnography. In Y. S. Lincoln \& N. K. Denzin (Eds.), Turning points in qualitative research. Tying the knots in a handkerchief (pp. 105-118). Walnut Creek, CA: AltaMira Press.

King, T. (2005). The truth about stories. A Native narrative. Minneapolis, MN: University of Minnesota Press.

Martin, J. (1827). An account of the natives of Tonga Islands in the South Pacific Ocean (Vol. 2). London: Constable.

McRae, K. O. (2010). Tangi and state funeral: Te Arikinui Dame Te Atairangikaahu and Prime Minister Norman Kirk. Masters of Social Science in Psychology Thesis. University of Waikato, Hamilton, New Zealand.

Mead, H. M. (2003). Tikanga Mãori: Living by Māori values. Wellington: Huia Publishers.

Mead, H. M., \& Grove, N. (2003). Ngā Pēpeha a ngā Tipuna. Wellington: Victoria University Press.

Melbourne, H. (1995). Maori sovereignty: The Maori perspective. Auckland: Hodder Moa Beckett.

Morrison, S. L. (2010). Iho Whakaue. Quintessentially Whakaue. Commissioned report prepared for Te Taumata o Ngāti Whakaue and Ministry of Education. Hamilton: University of Waikato.

Otsuka, S. (2005). Talanoa Research: Culturally appropriate research design in Fiji. Paper presented at the Proceedings of the Australian Association for Research in Education 
(AARE) 2005 International Education Research Conference: Creative Dissent Constructive Solutions. Melbourne, Australia: AARE. Retrieved from http://www.aare. edu.au/05pap/ots05506.pdf

Pere, R. R. (1982/1994). Ako. Concepts and learning in the Maori tradition. Hamilton: Department of Sociology, University of Waikato. Reprinted by Te Kohanga Reo National Trust Board.

Reed-Danahay, D. E. (1997). Auto/Ethnography: Rewriting the self and the social. Oxford: Berg.

Richardson, L. (2008). Writing theory in(to) autoethnography. The case of last writes. Paper presented at the Annual Meeting of the American Sociological Association, Boston. Retrieved from http://www.allacademic.com/meta/p239498_index.html

Ritchie, J. (2005). "It's the Controlling Still". Power effects in the implementation of the bicultural/bilingual early childhood curriculum in Aotearoa/New Zealand. In S. May, M. Franken, \& R. Barnard (Eds.), LED2003: Refereed Conference Proceedings of the 1st International Conference on Language, Education and Diversity. (CD-Rom ed.). Hamilton: Wilf Malcolm Institute of Educational Research, University of Waikato.

Ritchie, J. E. (1992). Becoming bicultural. Wellington: Huia Publications.

Ritchie, T. W. (2010). Reflections on a 'bicultural' tangihanga. Directed Study, Maori and Psychology Research Unit. Hamilton: University of Waikato.

Rose, D. B. (2000). Dingo makes us human. Life and land in an Australian Aboriginal culture. Cambridge: Cambridge University Press.

Sharp, A. (1995). Why be bicultural? In M. Wilson \& A. Yeatman (Eds.), Justice and identity: antipodean practices (pp. 116-133). Wellington: Bridget Williams Books.

Simon, J. (1989). Aspirations and Ideology: Biculturalism and multiculturalism in New Zealand education. Sites, 18, 23-34.

Sinclair, K. P. (1990). Tangi: Funeral riturals and the construction of Maori identity. In J. Linnekin \& L. Poyer (Eds.), Cultural identity and ethnicity in the Pacific (pp. 219-236). Honolulu: University of Hawaii Press.

Smith, G. H. (1992). Education: Biculturalism or separatism. In D. Novitz \& B. Willmott (Eds.), New Zealand in crisis. A debate about today's critical issues. Wellington: G.P. Publications.

Smith, L. T. (1999). Decolonizing methodologies. Research and indigenous peoples. London and Dunedin: Zed Books Ltd and University of Otago Press.

Spoonley, P. (1990). Racism, Race Relations and the Media. In P. Spoonley \& W. Hirsh (Eds.), Between the lines: Racism and the New Zealandmedia (pp. 26-37). Auckland: Heinemann Reid.

Statistics New Zealand. Tatauranga Aotearoa. (2011). Estimated resident population of New Zealand. Wellington: Statistics New Zealand. Tatauranga Aotearoa. Retrieved from http://www.stats.govt.nz/tools_and_services/tools/population_clock.aspx

Sullivan, D. (2007). Beyond biculturalism. The Politics of an indigenous minority. Wellington: Huia.

Sullivan, K. (1993). Bicultural education in Aotearoa/New Zealand: Establishing a Tauiwi side to the partnership. New Zealand Annual Review of Education, 3, 191-221.

Swadener, B. B., \& Mutua, K. (2008). Decolonizing performances. Deconstructing the global postcolonial. In N. K. Denzin, Y. S. Lincoln \& L. T. Smith (Eds.), Handbook of critical and indigenous methodologies (pp. 31-43). Los Angeles, CA: Sage.

Tahi, B. (1995). Biculturalism: The Model of Te Ohu Whakatipu. In M. Wilson \& A. Yeatman (Eds.), Justice and identity: Antipodean practices (pp. 61-77). Wellington: Bridget Williams Books. 
Tiatia, J. (1998). Caught between cultures: A New Zealand-born Pacific Island perspective. Auckland, New Zealand: Christian Research Association.

Vaioleti, T. M. (2011). Talanoa, manulua and foungaako: Frameworks for using Tongan concepts in contemporary classrooms in Aotearoa/New Zealand. Unpublished Ph.D. thesis. Hamilton: University of Waikato.

Vaioleti, T. M., Morrison, S. L., \& Vermeulen, W. (2002). Training for trainers in participatory learning in Samoa: Commissioned report for the European Commission, METI. Apia, Western Samoa.

Vasil, R. (1988). Biculturalism - Reconciling Aotearoa with New Zealand. Wellington: Victoria University Press for the Institute of Policy Studies.

Walker, R. (1987c). The meaning of biculturalism. Auckland: Maori Studies Section, Anthropology Department, Auckland University.

West-Newman, C. L. (2004). Anger, ethnicity, and claiming rights. Ethnicities, 4, $27-52$.

Wetherell, M., \& Potter, J. (1992). Mapping the language of racism. Discourse and the legitimation of exploitation. New York, NY: Columbia University Press. 